\title{
Immunization history of children with inflammatory bowel disease
}

\author{
Ing Shian Soon MD, Jennifer CC deBruyn MSc MD, Iwona Wrobel MD
}

IS Soon, JCC deBruyn, I Wrobel. Immunization history of children with inflammatory bowel disease. Can J Gastroenterol 2013;27(4):213-216.

BACKGROUND: Protection against vaccine-preventable diseases is important in children with inflammatory bowel disease (IBD) due to frequent immunosuppressive therapy use. The chronic relapsing nature and treatment regimen of IBD may necessitate modified timing of immunizations.

OBJECTIVE: To evaluate the completeness of immunizations in children with IBD.

METHODS: Immunization records of all children with IBD followed at the Alberta Children's Hospital (Calgary, Alberta) were reviewed. For children with incomplete immunization according to the province of Alberta schedule, the reasons for such were clarified. Demographic data and age at diagnosis were also collected.

RESULTS: Immunization records were obtained from 145 (79\%) children with IBD. Fifteen children had incomplete routine childhood immunizations, including two with no previous immunizations. The most common incomplete immunizations included hepatitis $B(n=9)$, diphtheria, tetanus, acellular pertussis at 14 to 16 years of age $(n=7)$, and diphtheria, tetanus, acellular pertussis, inactivated polio at four to six years of age $(n=6)$. The reasons for incomplete immunization included use of immunosuppressive therapy at time of scheduled immunization; IBD-related symptoms at time of scheduled immunization; parental refusal; recent move from elsewhere with different immunization schedule; unawareness of routine immunization; and needle phobia.

CONCLUSIONS: Although the majority of children with IBD had complete childhood immunizations, suboptimal immunizations were present in $10 \%$. With increasing use of immunosuppressive therapy in IBD, physicians caring for children with IBD must periodically evaluate immunization status and ensure the completeness of childhood immunizations.

Key Words: Immunization; Immunosuppressive agents; Inflammatory bowel diseases

\section{Les antécédents de vaccination des enfants atteints d'une maladie inflammatoire de l'intestin}

HISTORIQUE : Il est important de protéger les enfants atteints d'une maladie inflammatoire de l'intestin (MII) contre les maladies évitables, car ils prennent souvent des immunosuppresseurs. En raison des rechutes chroniques et du schéma thérapeutique caractéristiques des MII, il peut être nécessaire de modifier le moment d'administration des vaccins.

OBJECTIF : Évaluer si les enfants atteints d'une MII reçoivent tous les vaccins prévus.

MÉTHODOLOGIE : Les chercheurs ont examiné le dossier de vaccination de tous les enfants atteints d'une MII suivis à l'Alberta Children's Hospital de Calgary, en Alberta. Lorsque le dossier d'un enfant n'était pas complet d'après le calendrier de la province de l'Alberta, ils en vérifiaient les raisons. Ils ont également colligé leurs données démographiques et leur âge au diagnostic.

RÉSULTATS : Les chercheurs ont obtenu le dossier de vaccination de 145 enfants atteints d'une MII (79\%). Quinze enfants n'avaient pas reçu tous les vaccins systématiques prévus, dont deux qui n'en avaient reçu aucun. Les vaccins les moins administrés étaient ceux contre l'hépatite B $(n=9)$, contre la diphtérie, le tétanos et la coqueluche acellulaire entre 14 et 16 ans $(n=7)$, et contre la diphtérie, le tétanos, la coqueluche acellulaire et la polio inactivée entre quatre et six ans $(n=6)$. Les vaccins n'avaient pas tous étés administrés parce que l'enfant prenait des immunosuppresseurs ou avait des symptômes liés au MII au moment prévu pour leur administration, parce que les parents avaient refusé, avaient récemment déménagé d'un endroit où le calendrier de vaccination était différent ou ne connaissaient pas le calendrier de vaccination, ou parce que l'enfant avait peur des aiguilles. CONCLUSION : Même si la majorité des enfants atteints d'une MII avait reçu tous les vaccins prévus, la vaccination était sous-optimale chez $10 \%$ d'entre eux. Compte tenu de l'utilisation croissante d'immunosuppresseurs pour traiter les MII, les médecins qui soignent des enfants atteints d'une MII devraient évaluer périodiquement leur statut vaccinal et s'assurer qu'ils ont reçu tous les vaccins prévus.

Given the increased risk of infections in patients with IBD, immunization against vaccine-preventable infections is crucial. Patients with IBD should be immunized according to the same schedule as the general population, except for those who are currently on immunosuppressive therapies. Live-virus vaccines including measles, mumps and rubella, varicella, yellow fever, oral polio and rotavirus, and inhaled influenza vaccines are contraindicated for patients on immunosuppressive therapy due to risks of vaccine-associated infections, as recommended by the American Academy of Pediatrics (4) and the Canadian Immunization Guidelines (5). These include patients on an equivalent dose of prednisone ( $\geq 20 \mathrm{mg} /$ day or $2 \mathrm{mg} / \mathrm{kg} /$ day in children), 6-mercaptopurine, azathioprine, methotrexate and antitumour necrosis factor therapies. Patients who are treated with systemic corticosteroids for $<14$ days may receive live-virus vaccine immediately

Division of Paediatric Gastroenterology, Department of Paediatrics, Alberta Children's Hospital, University of Calgary, Calgary, Alberta

Correspondence: Dr Iwona Wrobel, Department of Paediatrics, University of Calgary, Alberta Children's Hospital, 2888 Shaganappi Trail Northwest,

Calgary, Alberta T3B 6A8. Telephone 403-955-7721, fax 403-955-2922, e-mail iwona.wrobel@albertahealthservices.ca

Received for publication August 20, 2012. Accepted September 5, 2012. 
TABLE 1

Patient characteristics

\begin{tabular}{lccc}
\hline & \multirow{2}{*}{\begin{tabular}{c} 
Patients \\
enrolled \\
\cline { 3 - 4 } Characteristic
\end{tabular}} & $\begin{array}{c}\text { Complete } \\
(\mathbf{n}=\mathbf{1 4 5})\end{array}$ & $\begin{array}{c}\text { Incomplete } \\
(\mathbf{n}=\mathbf{1 3 0})\end{array}$ \\
\hline Male sex & $81(56)$ & $73(56)$ & $8(53)$ \\
Age, years, median & $(\mathrm{Q} 1, \mathrm{Q} 3)$ & & \\
$\quad$ At enrollment & $15.7(13.2,17.6)$ & $15.6(13.4,17.6)$ & $15.9(12.6,18.2)$ \\
At diagnosis & $11.9(9.3,14.4)$ & $12.0(9.3,14.5)$ & $10.7(8.5,14.2)$ \\
Diagnosis & & & \\
Crohn disease & $77(53)$ & $68(52)$ & $9(60)$ \\
Ulcerative colitis & $53(37)$ & $48(37)$ & $5(33)$ \\
Indeterminate colitis & $15(10)$ & $14(11)$ & $1(7)$ \\
\hline
\end{tabular}

Data presented as $n$ (\%) unless otherwise indicated. Q Quartile

after discontinuation of treatment, whereas patients who are treated for $\geq 14$ days should not receive live-virus vaccine until corticosteroids have been discontinued for at least one month (4). Guidelines regarding immunization for patients with IBD (6) and specifically for patients on immunmodulators and biologics (7) emphasize that the immunization schedule for patients with IBD should not differ from the general recommendations except for those on immunosuppressive therapy. Despite these recommendations, vaccination rates in highrisk populations due to immunosuppressive therapy remain low (8-11). Melmed et al (12) assessed the immunization history and exposure risk to vaccine-preventable diseases in 169 patients with IBD. Of the patients at risk, only $28 \%$ received hepatitis B immunizations, $28 \%$ received regular influenza immunizations, $9 \%$ received a pneumococcal vaccination and $45 \%$ received a tetanus vaccination within the previous 10 years. Despite the risk of infections in IBD patients on immunosuppressive therapy and the benefit of vaccination, there is a paucity of knowledge in the literature about the rate of routine childhood immunizations in children with IBD.

The primary objective of the present study was to estimate the proportion of children with IBD with complete routine childhood immunization according to the recommended routine Alberta immunization schedule. The secondary objective was to explore the reasons for incomplete immunization in these children.

\section{METHODS}

A cross-sectional study of children with IBD followed at the Alberta Children's Hospital (Calgary, Alberta) from October 2008 to September 2009 was conducted. The Alberta Children's Hospital is the only tertiary-care pediatric hospital in Southern Alberta, serving a population of 1.5 million including western Saskatchewan and eastern British Columbia. All children with IBD in southern Alberta are followed by the pediatric gastroenterology team at the Alberta Children's Hospital. Invitation letters were mailed to all families of children with IBD followed by the pediatric gastroenterology team. These were followed by telephone calls. A copy of the child's immunization record was obtained either from the public health office, where all childhood immunizations are administered, or from personal immunization cards, which are recorded by the public health officer when immunizations are given. Demographic information including sex, age and IBD history, including age at diagnosis and disease classification, were also collected. A complete immunization record was defined as patients who had received all the routine childhood immunization appropriate for age at the time of enrollment (Table 1). Varicella vaccination was excluded because it was not implemented in all provinces and territories of Canada until 2007. The influenza vaccine was not included because it is usually not given at the public health office where other routine childhood immunizations are given; hence, its documentation may be inconsistent in the immunization database and personal health record. Furthermore, given that immunization is recommended yearly, definition of complete status may be difficult. Human papillomavirus
TABLE 2

Number of children with incomplete immunization according to the Alberta routine immunization schedule

\begin{tabular}{llcc}
\hline Age & Vaccine & $\begin{array}{c}\text { Children with } \\
\text { incomplete } \\
\text { vaccination, }\end{array}$ & $\begin{array}{c}\text { Age at Dx, } \\
\text { years, } \\
\text { median }\end{array}$ \\
\hline 2 months & $\cdot$ DTaP-IPV-Hib & 2 & 14.6 \\
& $\cdot$ Pneumococcal conjugate & & \\
& $\cdot$ Meningococcal conjugate & & 14.6 \\
4 months & $\cdot$ DTaP-IPV-Hib & 2 & \\
& $\cdot$ Pneumococcal conjugate & & 14.6 \\
6 months & $\cdot$ Meningococcal conjugate & & 14.6 \\
12 months & $\cdot$ DTaP-IPV-Hib & 2 & 11.9 \\
18 months & $\cdot$ Mneumococcal conjugate & & \\
4 to 6 years & $\cdot$ MTaP-IPV-Hib & 2 & 8.1 \\
Grade 5 & $\cdot$ DTaP-IPV- MMR & & 11.8 \\
14 to 16 years & $\cdot$ dTap & 3 & 13.6 \\
\hline
\end{tabular}

DTaP-IPV-Hib Diphtheria, tetanus, acellular pertussis, polio, haemophilus influenza type b; MMR Measles, mumps and rubella; dTap Diphtheria, tetanus, acellular pertussis; DTaP-IPV Diphtheria, tetanus, acellular pertussis, inactivated polio; Dx Diagnosis

vaccine was not included because it had only been recently introduced to the immunization program of Alberta for grade 5 students in 2008. For individuals with incomplete immunization records, the reasons for incomplete immunization were sought by telephone. Demographic data of patients who did not respond were documented and compared with those who responded.

Similar to other provinces in Canada, Alberta's universal health care plan provides all legal residents free access to health services including routine childhood immunizations (Table 2). The immunization records for southern Alberta are maintained in the Phantim and Medipatient databases by the public health office and are accessible via the public health office. Because immunization histories were obtained from either the public health office or personal immunization cards, misclassification of immunization history was unlikely.

\section{Statistical analysis}

Immunization records were entered into a database for descriptive analysis using a spreadsheet (Excel XP, Microsoft Corporation, USA). Baseline characteristics for patients with complete immunizations were compared with those with incomplete immunizations. $\chi^{2}$ tests were used for categorical variables and Student's $t$ tests were used for continuous variables. All statistical analyses were performed using STATA version 11.0 (13); $\mathrm{P}<0.05$ was considered to be statistically significant.

Ethics considerations

The present study was approved by the Conjoint Health Research Ethics Board of the University of Calgary, Calgary, Alberta.

\section{RESULTS}

Invitation letters were mailed to 184 children with IBD followed at the Alberta Children's Hospital Gastroenterology Clinic; 39 patients were excluded (refusal to participate $[n=7]$ and no response $[n=32]$ ). Demographic characteristics, including age at diagnosis and enrollment, sex, area of residence and type of IBD, were similar among responders and nonresponders.

Immunization records were thus obtained from 145 (79\%) children with IBD. The median age of participants was 15.7 years and the median age at diagnosis was 11.9 years. 
Of 145 patients, 130 received all routine childhood immunizations (complete immunization rate 90\%). Among the 15 patients with incomplete immunizations, two had never been vaccinated, eight had missed two or more vaccinations, and six had incomplete live-virus vaccinations. The baseline characteristics (Table 1) demonstrated no difference in sex, age and type of IBD between those with complete and incomplete immunizations. However, there was a trend toward younger age at diagnosis in those with incomplete immunizations compared with those with complete immunizations (median age 10.7 years versus 12.0 years).

The number of children with incomplete immunizations as per the routine Alberta immunization schedule is summarized in Table 2. The most commonly missed immunizations were diphtheria, tetanus, acellular pertussis and polio, and measles, mumps and rubella at four to six years of age; hepatitis $\mathrm{B}$ given in grade 5 at nine to 10 years of age years; and diphtheria, tetanus and acellular pertussis ( $\mathrm{dTaP}$ ) booster at 14 to 16 years of age. Excluding the two patients who had never been vaccinated, the remainder of the cohort all received complete immunizations in the first year of life.

The reasons for incomplete childhood immunization were categorized as IBD-related and non-IBD-related; use of immunosuppressive therapy at the time of scheduled immunization was the most common reason $(n=6)$. Of the patients with incomplete live-virus immunizations, only one was due to immunosuppressive therapy at time of scheduled immunization. Disease flare at the time of scheduled immunization was another IBD-related reason $(n=2)$. Non-IBD reasons for incomplete immunizations included parental refusal, recent move from another province or country with different immunization schedule, needle phobia and lack of awareness of routine immunization. Only $33 \%$ of incomplete immunizations were due to IBD-related reasons (Table 3 ).

\section{DISCUSSION}

In the present study, we demonstrated that children with IBD had a high rate of complete routine childhood immunizations (90\%), exceeding that of the general population in Canada. This was a self-selected cohort with a potential for selection bias given that the vaccination rate among responders and nonresponders may vary. Assuming that nonresponders had incomplete routine childhood immunizations, the lowest rate of complete immunization in our pediatric IBD population would be estimated to be $71 \%$. Nevertheless, similar demographic characteristics among responders and nonresponders (age, sex, area of residence and type of IBD) make a higher rate more likely. In the Canadian National Immunization Coverage Survey published in 2006 (14), only $73 \%$ to $78 \%$ of Canadian two-year-olds were immunized against $\mathrm{dTaP}$ and $73 \%$ were immunized against haemophilus influenza type b in 2004. Given the high response rate (79\%) in the sole pediatric gastroenterology referral centre for Southern Alberta and the inclusion of all IBD types, and similar demographic characteristics among responders and nonresponders (age, sex, area of residence and type of IBD), these results may be generalized to children with IBD in Alberta. The high rate of complete routine childhood immunization in our cohort may be attributed to the comprehensive publicly funded immunization programs in Alberta. The National Advisory Committee on Immunization makes recommendations on the use of vaccines and national vaccination strategies in Canada. However, it is up to the individual province to implement the strategies; hence, immunization practices may differ from province to province in Canada. Although the majority of children with IBD had complete childhood immunization, suboptimal immunizations were present in 10\%. Most commonly, these were for non-IBD related reasons. However, use of immunosuppressive therapies was a reported reason for missed immunization. The American Academy of Pediatrics (4) and the Canadian Immunization Guidelines (5) recommend that individuals be immunized according to the general population schedule, except for live-virus vaccines for those on immunosuppressive therapies. The use of immunosuppressive therapies is not a contraindication to receiving inactivated immunizations.

\section{TABLE 3}

Reasons for incomplete childhood immunization

\begin{tabular}{|c|c|}
\hline $\begin{array}{l}\text { Reason for incomplete } \\
\text { immunization }\end{array}$ & Incomplete immunization \\
\hline \multicolumn{2}{|l|}{ IBD-related } \\
\hline $\begin{array}{l}\text { Use of immunosuppressive } \\
\text { therapy at time of scheduled } \\
\text { immunization }(n=6)\end{array}$ & $\begin{array}{l}\text { MMR and DTaP-IPV at } 4 \text { to } 6 \text { years of age }(n=1) \\
\text { Hepatitis B }(n=4) \\
\text { dTaP at } 14 \text { to } 16 \text { years of age }(n=1)\end{array}$ \\
\hline $\begin{array}{l}\text { Disease flare at time of } \\
\text { scheduled immunization } \\
(n=2)\end{array}$ & $\begin{array}{l}\text { DTaP-IPV-Hib and pneumococcal conjugate } \\
\text { at } 18 \text { months }(n=1) \text { MMR and DTaP-IPV } \\
\text { at } 4 \text { to } 6 \text { years of age }(n=1) \\
\text { dTaP at } 14 \text { to } 16 \text { years of age }(n=1)\end{array}$ \\
\hline \multicolumn{2}{|l|}{ Non-IBD related } \\
\hline Parental refusal $(n=4)$ & $\begin{array}{l}\text { Never immunized }(n=2) \\
\text { MMR and DTaP-IPV at } 4 \text { to } 6 \text { years of age } \\
\quad(n=1) \text {, hepatitis } B(n=1) \\
\text { dTap at } 14 \text { to } 16 \text { years of age }(n=1)\end{array}$ \\
\hline $\begin{array}{l}\text { Recent move from elsewhere } \\
\text { with different immunization } \\
\text { schedule }(n=2)\end{array}$ & $\begin{array}{l}\text { MMR and DTaP-IPV at } 4 \text { to } 6 \text { years of age }(n=1) \\
\text { Hepatitis } B(n=2) \\
\text { dTap at } 14 \text { to } 16 \text { years of age }(n=1)\end{array}$ \\
\hline Needle phobia $(n=1)$ & Hepatitis B $(n=1)$ \\
\hline $\begin{array}{l}\text { Lack of awareness of routine } \\
\text { immunization }(n=1)\end{array}$ & dTap at 14 to 16 years of age $(n=1)$ \\
\hline
\end{tabular}

dTap Diphtheria, tetanus, acellular pertussis; DTaP-IPV Diphtheria, tetanus, acellular pertussis, inactivated polio; IBD Inflammatory bowel disease; MMR Measles, mumps and rubella

However, there may be suboptimal response to immunization while on immunosuppressive therapy (15-17). If immunosuppressive therapy is temporary, then catch-up immunization may be administered after cessation of immunosuppressive therapy. If long-term immunosuppressive therapy is required, the benefit of immunization in protecting against vaccine-preventable infections must be communicated to the family.

Disease flare at time of scheduled immunization was another reported reason for incomplete immunization. Families may be concerned about worsening of disease activity with immunization given that IBD is an immune-mediated disease. In a study examining influenza vaccine immunogenicity and safety in children with IBD (15), the majority of children tolerated vaccination without worsening of their disease activity. However, if the decision was made to delay immunization during disease flare, clinicians should ensure that catchup immunization is completed at a later date.

Immunization status should, therefore, be evaluated at diagnosis and before initiation of immunosuppressive therapy in children with IBD. Patients and families should be educated about the optimal timing and catch-up of immunization during regular visits but especially when exposed to immunosuppressive therapy.

DISCLOSURE: Ing Shian Soon is supported by the Alberta Children's Hospital Research Institute for Child and Maternal Health and the Canadian Institutes of Health Research (CIHR) Training Program in Genetics, Child Development and Health research fellowship. This research was supported by an Alberta Children's Hospital Foundation Research Grant.

\section{REFERENCES}

1. Deutsch DE, Olson AD, Kraker S, Dickinson CJ. Overwhelming varicella pneumonia in a patient with Crohn's disease treated with 6-mercaptopurine. J Pediatr Gastroenterol Nutr 1995;20:351-3.

2. Esteve M, Saro C, Gonzalez-Huix F, Suarez F, Forne M, Viver JM. Chronic hepatitis B reactivation following infliximab therapy in Crohn's disease patients: Need for primary prophylaxis.

Gut 2004;53:1363-5. 
3. Leung VS, Nguyen MT, Bush TM. Disseminated primary varicella after initiation of infliximab for Crohn's disease. Am J Gastroenterol 2004;99:2503-4.

4. Pickering LK, Baker CJ, Kimberlin DW, Long SS. Red Book: 2009 Report of the Committee on Infectious Diseases, 28th edn. Elk Grove Village: American Academy of Pediatrics; 2009.

5. Canadian Immunization Guide, 7th edn. Ottawa: Public Health Agency of Canada; 2006.

6. Sands BE, Cuffari C, Katz J, et al. Guidelines for immunizations in patients with inflammatory bowel disease. Inflamm Bowel Dis 2004;10:677-92.

7. Melmed GY. Vaccination strategies for patients with inflammatory bowel disease on immunomodulators and biologics. Inflamm Bowel Dis 2009;15:1410-6.

8. Duchini A, Goss JA, Karpen S, Pockros PJ. Vaccinations for adult solid-organ transplant recipients: Current recommendations and protocols. Clin Microbiol Rev 2003;16:357-64.

9. Davies K, Woo P, British Paediatric Rheumatology G. Immunization in rheumatic diseases of childhood: An audit of the clinical practice of British Paediatric Rheumatology Group members and a review of the evidence. Rheumatology 2002;41:937-41.

10. Burroughs M, Moscona A. Immunization of pediatric solid organ transplant candidates and recipients. Clin Infect Dis 2000;30:857-69.
11. Bridges MJ, Coady D, Kelly CA, Hamilton J, Heycock C. Factors influencing uptake of influenza vaccination in patients with rheumatoid arthritis. Ann Rheum Dis 2003;62:685.

12. Melmed GY, Ippoliti AF, Papadakis KA, et al. Patients with inflammatory bowel disease are at risk for vaccine-preventable illnesses. Am J Gastroenterol 2006;101:1834-40.

13. Stata Statistical Software. College Station: Stata Corporation; 2009.

14. Public Health Agency of Canada. Canadian National Report on Immunization, 2006. CCDR Nov 2006;32S3:1-44.

15. deBruyn JC, Hilsden R, Fonseca K, et al. Immunogenicity and safety of influenza vaccination in children with inflammatory bowel disease. Inflamm Bowel Dis 2012;18:25-33.

16. Lu Y, Jacobson DL, Ashworth LA, et al. Immune response to influenza vaccine in children with inflammatory bowel disease. Am J Gastroenterol 2009;104:444-53.

17. Mamula P, Markowitz JE, Piccoli DA, Klimov A, Cohen L, Baldassano RN. Immune response to influenza vaccine in pediatric patients with inflammatory bowel disease. Clin Gastroenterol Hepatol 2007;5:851-6. 


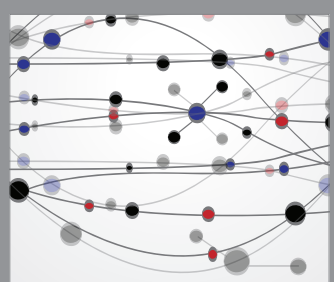

The Scientific World Journal
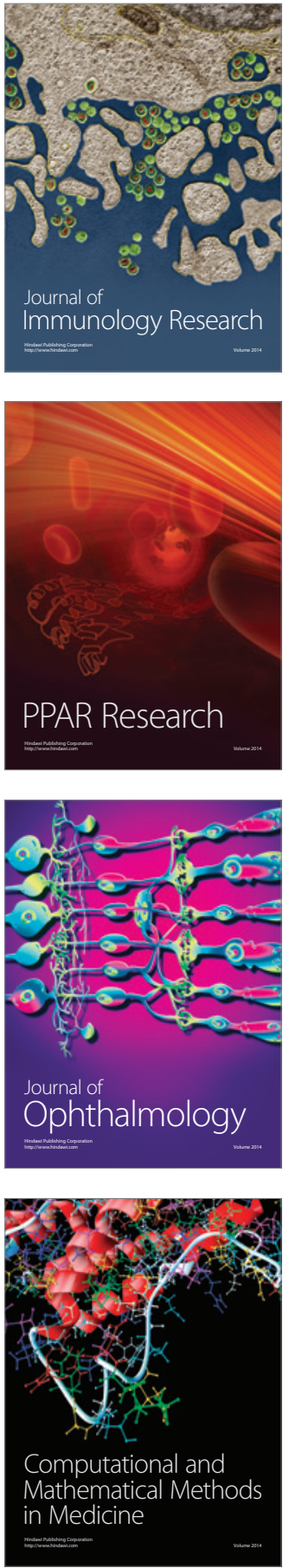

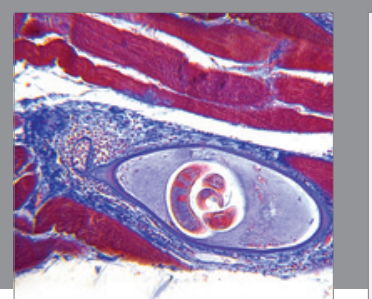

Gastroenterology Research and Practice

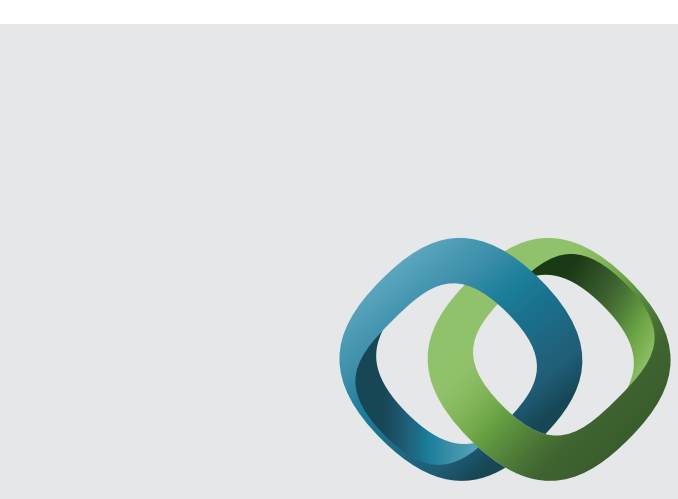

\section{Hindawi}

Submit your manuscripts at

http://www.hindawi.com
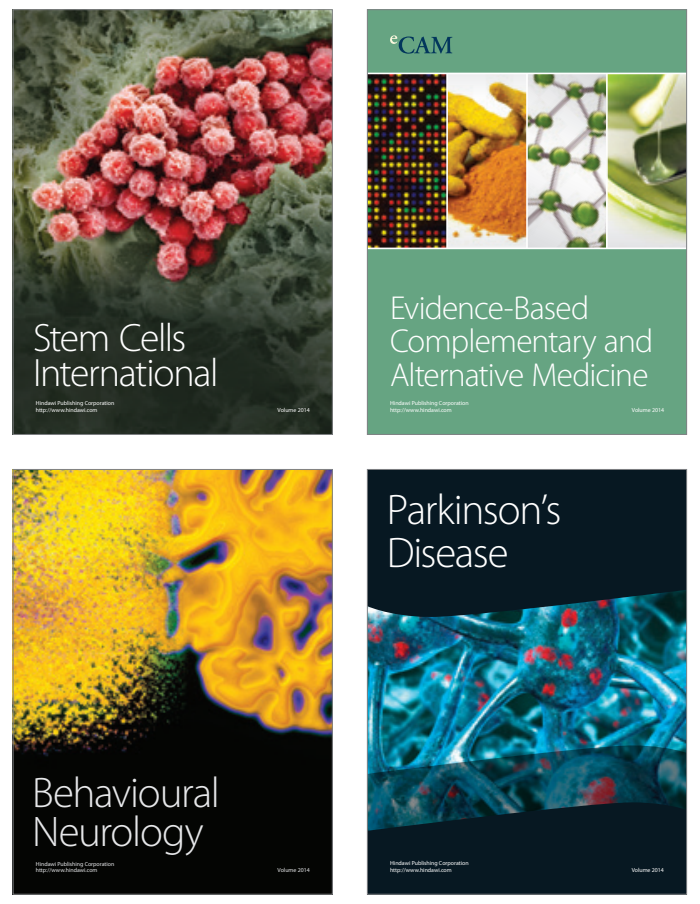
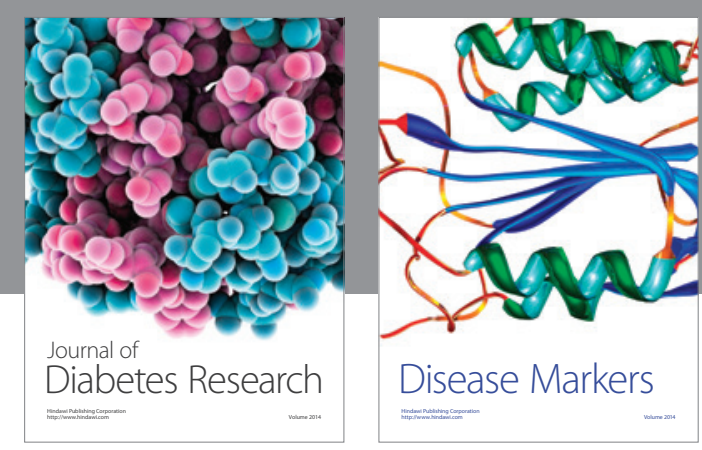

Disease Markers
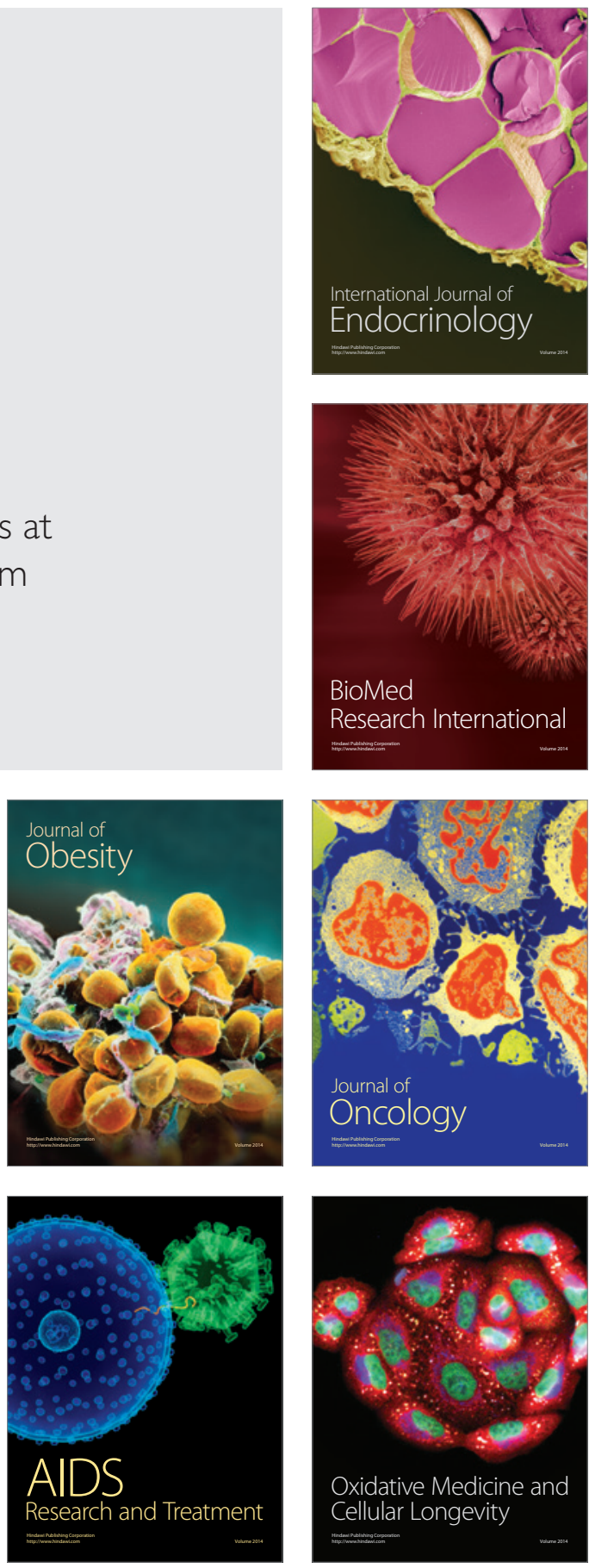